\title{
DISCOVERING ENGLISH TENSE-BACKSHIFT PARAMETERS THROUGH DISCOURSE
}

\section{INTRODUCTION}

The main objective of The Council of Europe's Common European Framework of Reference for Languages (CEFR) 1 is to improve the communicative competence of " $\mathrm{Eu}$ ropean citizens" and foster transparency in language qualifications. The CEFR provides comprehensive guidelines for language learning, teaching and assessment. This article focuses on the learning strategies that develop the learner's communicative competence; it makes reference to English tense-backshift parameters in indirect discourse (or so-called "reported speech") $)^{3}$. The CEFR's guidelines can be easily applied to the topic of indirect discourse usage. The development of the communicative competence thus proceeds:

- from the acquisition of the linguistic components, i.e. tense backshift as a grammatical feature,

- to the sociolinguistic components, e.g. detached attitude in interpersonal relations,

- and to the pragmatic components, i.e. discursive parameters, which are the main objective of this presentation.

The discourse-oriented approach to learning indirect discourse parameters comes closest to the intuitive tense-backshift acquisition in native speakers.

Pedagogical consideration of this topic has so far not shown sufficient sensitivity either to different types of discourse in which indirect discourse is used or to the intentions of the "reporter" in deciding whether to apply tense-backshift in contexts where this is a grammatical option. In our approach learners and students of English are encouraged to observe indirect discourse in diverse authentic contexts in order to better understand its parameters; also, there is a particular focus on tense-backshift, since Slovenian is a language with no such grammatical feature.

* Author's address: Filozofska fakulteta, Univerza v Ljubljani, Aškerčeva 2, 1000 Ljubljana, Slovenia. E-mail: silvana.orelkos@ff.uni-lj.si.

1 Source: Common European Framework of Reference for Languages: Learning, Teaching, Assessment (2001). Cambridge: Cambridge University Press. http://www.coe.int/t/dg4/linguistic/ Source/Framework_EN.pdf (Accessed 2 August 2014).

2 As the article focuses on the development of learning strategies that apply to the communicative competence as designed by the CEFR, we prefer to use the terms "learner" or "student" to the general designation "European citizen".

3 Payne (2011: 344) notes that the term reported speech is "sometimes" used as a cover term for both "direct and indirect speech". 


\subsection{English tense-backshift}

In English, tense-backshift is a grammatical procedure of shifting or "regressing" the original temporal finite verb form by one tense backwards. In grammars and teaching materials, tense-backshift is mostly associated with reporting a spoken statement, i.e. reported speech, when the reporting verb, e.g. say, is expressed in the Past Tense within a written context.

Oral statements may be reported or repeated because of impaired listening comprehension during the communicative act or due to some temporal gap between the original statement and the communicative act in which the statement is recycled. However, there are statements that are reported without being first orally expressed, e.g. thoughts and emotional impressions, or which can be perceived via other means of sensory perception: sight, smell and touch. Therefore, in our approach, we use the broader term of indirect discourse to refer to reporting of both orally and non-orally expressed original statements.

Some of the diverse functions of indirect discourse can be observed in the following excerpt from a (self-published) fictional story found on-line ${ }^{4}$ :

“Jon, I'm pregnant." (1)

Did I just hear that right or am I going crazy? (2) Did my wife really just say that she was pregnant? (3)

"Wait, what did you just say?" (4) I said still confused.

"I said I'm pregnant." (5) She said looking like she was about to cry.

So I did hear her right, I'm not crazy. (2') When I looked at her again I realized she was crying (6) and I couldn't figure out why. I thought this was supposed to be a good thing. (7)

The story is told in the narrative Past Tense. Sentence (1) is the original oral statement by a married woman. Her husband, a first-person narrator, is so astonished by the statement that he thinks his hearing is impaired or that he is developing a mental problem (2). He wonders whether his wife really mentioned a pregnancy (3). He uses tense-backshift to express a distanced (externalized) attitude or his incredulity vis-àvis the original statement (1). He asks his wife to repeat her statement (4). His wife repeats her original message in the form of an informal orally reported statement in which the connective conjunction that is dropped and the sequence of tenses is not observed: she chooses not to express a distanced attitude towards her own message, but rather an internal one, as she considers it to be the focus of her communication with her husband (5). Sentences (6) and (7) show the narrator's ideas being introduced by the mental verbs realize and think. The narrator uses tense-backshift with verbs of mental perception. In English, thoughts are perceived to be strongly connected with the time of their first occurrence, so the indirect discourse producer is expected to adopt an external attitude.

4 Source: http://www.hockeyfanfiction.com/Story/16359/Dreams-Do-Come-True/10/; Author:Jacquelinetoews19 (Accessed 29 July 2014). 
Grammatical studies that explain the use of English tense-backshift tend to illustrate the feature in decontextualized sentences. The original utterance Jon, I'm pregnant might be represented by only a pair of sentences, showing that tense-backshift can either occur or not occur for the same original utterance:

Did my wife really just say that she was pregnant?

I said I'm pregnant.

A decontextualized, i.e. merely linguistic, consideration of the topic fails to show the type of discourse in which the above statements occur, it fails to show their communicative functions (note the omission of quotation marks for mimetic discourse in the second example), and it will disregard the sociolinguistic roles of the users producing these indirect statements. The statement Did my wife really just say that she was pregnant? includes not only information about the original speaker, i.e. the wife, but implies that the actual producer of the indirect sentence is her husband, a first-person reporter, which can be deduced from the possessive pronoun in the noun phrase my wife.

In more traditional syntactic analysis, reported (or indirect) speech is represented by two basic structures: the reporting clause is the main clause, while the reported clause is a nominal subordinate clause performing the function of Direct Object (DO):

"I said I'm pregnant."

I said

I'm pregnant

reporting clause - main clause

reported clause - subordinate clause (DO)

In communicative approaches to indirect discourse, the structuralist notions are complemented by further pragmatic categories. The reporting clause is associated with the original communicator, and the reported clause with the communicated message in the reported utterance, i.e. the proposition. The original communicator expresses his or her message via communication acts or speech acts, and these are represented by illocutionary verbs in reporting clauses. In the above example of indirect discourse, the original communicator "I", the wife, performs at the same time the function of the "reporter": the wife reports her own words.

The finite verb actions of the communicated message may refer to (a) hypothetical verb situations, such as modal verb actions and those expressing posteriority, i.e. futurity, (b) concrete dynamic verb situations simultaneous with or anterior to the time of utterance, and (c) stative situations, such as habits and states. In the above example, the finite verb in the statement I'm pregnant is a formally stative verb phrase, yet has current relevance.

\subsection{Communication verbs}

Longman Grammar of Spoken and Written English (LGSWE) uses a broader term, "communication verbs", to refer to reporting verbs. Communication verbs encompass three major semantic domains: "mental verbs, mainly of cognition (e.g. think, know), but including a few with emotive/affective content (e.g. hope and wish); speech act 
verbs (e.g. say, tell); and other communication verbs that do not necessarily involve speech (e.g. show, prove, suggest) [...]" (LGSWE 1999: 661).

Mental verbs and speech act verbs are primarily associated with animate subjects, while subjects of "other communication verbs" tend to be inanimate, e.g. the data. In the above excerpt taken from an on-line story, the speech act verb say and the mental verbs realize and think are used.

\section{THE COMMUNICATION MEDIATOR}

The most obvious feature of indirect discourse is its derivative nature: it involves communication through a "reporter", a secondary communicator or the communication mediator. Tense-backshift in English indirect discourse depends on the mediator's decision whether to focus on the original communicator, adopting an external perspective, or the communicated message, adopting an internal perspective.

The focus on the original communicator introduces a "filter" between the secondary communicator and the original message. It distances the communication mediator from the message, since the communication mediator is located externally, namely, in the present time-sphere or a time-sphere which is subsequent to the temporal sphere of the original message (cf. Declerck 1991: 173). In focusing on the communicated message, the mediator establishes a direct or internal link with the message, and the proposition is perceived to be located within the mediator's time-sphere.

Is the mediator's external/internal ${ }^{5}$ focus made on the spur of the moment, or is it governed by some restrictions or conventions? Let us consider the following excerpt from a grammar book for "English language professionals":

This shifting of tenses doesn't always happen. For example, either of the following is well formed:

Aristotle announced that the earth was a globe.

Aristotle announced that the earth is a globe (Jacobs 1993: 193).

Either sentence is indeed "well formed" or grammatically correct, and yet the above observation fails to consider the different types of discourse in which the above sentences might be naturally embedded. The following two excerpts taken from on-line articles show typical contexts in which the mediated propositions [the earth being a globe] is used:

(a) By the Middle Ages, there was widespread belief among the educated - at the very least - that the earth was a globe. Columbus did face opposition on his voyage, but not from people who thought he'd drop off the edge of the world. Instead people believed he'd predicted too small a globe and would run out of supplies before he made it round to Asia. ${ }^{6}$

5 A narrative approach to indirect discourse showing the narrator's role of external/internal focalizer is described by Fleischman (1990).

6 Source: http://europeanhistory.about.com/od/historicalmyths/a/histmyths7.htm; Author: Robert Wilde (Accessed 29 July 2014). 
(b) The ancients considered the Earth to be flat and located at the centre of the Universe, with the sky a crystal dome on which the stars were fixed. It was around $2000 \mathrm{BC}$ that Aristotle realised that the Earth is a globe. There is clear evidence to support this view. For instance, there is the differing altitude of the pole star as seen from different locations and the fact that the most southerly of the constellations are only rendered visible by travelling southwards (the converse is true for people living in the southern hemisphere). ${ }^{7}$

Example (a) contains a context in which the statement is embedded in a historical or narrative setting, whith the narrator maintaining a distanced attitude or an external perspective, while example (b) shows that the author, the secondary communicator, has some scientific interest in establishing a relevant link between Aristotle's observation and the general evidence to support the view, thus assuming an internal perspective.

\section{DISCOURSE}

The mediator's choice whether to use tense-backshift is not purely random. It is governed by a set of pragmatic conventions as well as semantic, stylistic and syntactic restrictions. We shall take a top-down approach to presenting the criteria, starting with discoursal macrostructures.

The first macrostructure that learners of English should be made aware of is the type of discourse, i.e. the macrotext type, in which indirect discourse is embedded. In indirect discourse teaching, learners are almost invariably presented with individual, decontextualized sentences illustrating the formal features of the sequence of tenses, rather than the function of indirect discourse in a particular type of discourse.

Indirect discourse functions can be observed with respect to the following macrotextual types of discourse: fiction, academic prose, news reporting and conversation. It is important that learners are also made aware of the roles that the communication mediators assume in the respective types of discourse: narrator, author, reporter and speaker. The narrator's role, for example, will differ from that of the speaker in everyday conversation.

Discourse type:

Fiction

Academic prose

News reporting

Conversation

\section{Communication mediator:}

Narrator

Author

Reporter

Speaker

7 Source: http://link.springer.com/chapter/10.1007/978-1-4471-0901-3_2; Author: Gerald North (Accessed 29 July 2014). 


\subsection{Fiction}

In fictional narratives, indirect discourse can be best studied within the narrated segments of the text, i.e. diegetic discourse. In diegetic discourse the narrator functions as the communication mediator. In mimetic discourse (dialogues), on the other hand, the role of the communication mediator is allotted to the character involved, the speaker. Owing to the conversational nature of mimetic discourse, the functions of indirect discourse there are expected to reflect the functions associated with conversation rather than with narrative fiction.

Corpus data show that backshifting is best observed in diegetic discourse with either an omniscient narrator or a narrator whose narration is completely embedded in the past time-sphere:

But now, walking past the group of doctors in the hall, he heard the woman's name, and he slowed his pace and turned and came up to them and asked specifically which hospital she was working in. They told him that it was an old nunnery, taken over by the Germans, then converted into a hospital after Allies had laid siege to it. In the hills north of Florence. Most of it torn apart by bombing. Unsafe. It had been just a temporary field hospital. But the nurse and the patient had refused to leave.

Why didn't you force the two of them down? ${ }^{8}$

In the above excerpt there are two original communicators: "he" and "they". The secondary communicator is the omniscient narrator, who is highly skilled in mediated discourse structures. Such a narrative is an ideal type of discourse for helping learners observe the regularities of tense-backshift with an external narrator. As simple as it appears to be, learners should nevertheless be first made aware of the fact that they are dealing with functions of indirect discourse in fiction, more specifically, with fiction embedded in the past time-sphere.

\subsection{Academic prose}

Academic prose is distinguishable from other macrotextual types of discourse in that the high-frequency speech act verbs say and tell are for obvious reasons excluded from its array of reporting verbs, unless the discourse happens to include narrative stretches of indirect discourse - for example a study including some historical background on the development of a scientific idea. Given that in academic prose the communicated message is of general or universal validity and of greater importance than the original communicator, the author of academic prose may be expected to focus on the communicated message, thus reporting from his or her present (internal) time-sphere, rather than the past time-sphere of the original communicator, as is shown by the following example:

The same problem arises with (36).

(36) Colorless green ideas sleep furiously.

8 ONDAATJE, Michael (1992) The English Patient. London: Picador, p. 28. 
Chomsky (1957) argued that (36) shows that there is a notion of syntactic well-formedness, which must be distinguished from semantic well-formedness, since the syntactically well-formed (36) has a status radically different from sentences that are both syntactically and semantically ill formed, like (37), for example:

(37) sleep colorless furiously ideas green

But given current assumptions, the well-formedness of (36) cannot be strictly syntactic. ${ }^{9}$

The mediator here focuses on the message which was communicated by Chomsky in 1957. What is relevant to the present academic author is not the temporal placement of Chomsky's message, but the atemporal validity of the message.

\subsection{News reporting}

News reporting makes for a complex area of study, since it features both written and spoken modes of communication, diverse subject areas and cultural differences. The communication mediator is a reporter whose actual job is to report other people's communication. This makes news reporting the most prominent domain of text production that is dependent on other people's statements.

News reporting may indicate the mediator's attitude towards what is being communicated. The mediator may opt either for a distanced (external) or an intimate (internal) attitude. In adopting a distanced attitude the reporter focuses on the original communicator. In so doing, the responsibility for the utterance is delegated to the original communicator. In adopting an intimate attitude, the reporter focuses on the communicated message, and the message is ascribed general or unbiased validity.

In contrast to other types of discourse, indirect discourse found in news reporting, e.g. in political reports or accident reports, involves a wide variety of original communicators, such as named politicians, spokesmen, police, or witnesses. These figures exercise different degrees of authority or power. It is more likely for the reporter to choose a distanced attitude, i.e. tense backshift, when reporting a statement made by George W. Bush (c) rather than with an accident description provided by anonymous witnesses (d):

(c) WASHINGTON: President George W. Bush said Thursday for the first time that the

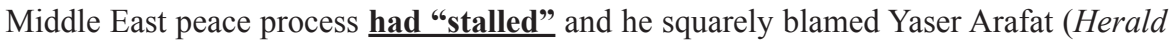
Tribune, September 19, 2003).

(d) Witnesses said the fire came from an Israeli tank at the Misgav'am settlement (The Gu$\left.\operatorname{ardian}^{*}\right){ }^{10}$

9 BOUCHARD, Denis (1995) The Semantics of Syntax: A minimalist approach to grammar. Chicago and London: The University of Chicago Press, p. 43.

10 Acknowledgements: The author is grateful to the following students for the examples they provided in their seminar papers: Maja Mrak and Emanuela Bubanj (films and series marked with *), Anja Čibej, Lučka Lučovnik, Ksenija Murn, Alenka Čop, Elvira Matko, Mihaela Orozel and Polona Volavšek (newspaper examples marked with *). 
Another important convention in news reporting is the relationship between discrete statements and narrative-like strings of utterances. For instance, in a trial report, the reporter may prefer to focus on the communicated message, the testimonies, rather than the original communicators, i.e. the witnesses. In so doing, the reporter presents the testimonies in the form of a lively story in standard narrative tenses, so there is no backshift, even though the story consists of reported oral statements:

A WOMAN police constable described yesterday how she walked alone through a deserted park in the early hours to lure a suspected rapist.

Claire Fisher, 25, spoke of her terror as she heard his breathing in the shadows and as he stalked her before attacking.

When he struck she was grabbed around the neck and dragged towards a car park before police colleagues moved in to spring the trap.

Miss Fisher told the Old Bailey how she agreed to act as bait for Darrin Akinyemi, who detectives believed had sexually abused a 15-year-old girl and raped a 22-year-old French au pair in Norman Park, Hammersmith, West London.

Akinyemi, 25, denies rape, attempted rape, indecent assault, abduction and causing actual bodily harm (Daily Mail, November 16, 1999).

Note, however, that there are differences in the application of indirect discourse with speech act verbs, e.g. speak, tell, and mental verbs such as believe (for details see the section on Semantic conventions).

\subsection{Conversation}

With the emergence of corpus linguistics, the study of indirect discourse in conversation has been gaining authenticity. For instance, the study of direct and indirect speech reporting in Longman Grammar of Spoken and Written English (Biber et al. 1999) is based on corpus examples. On the basis of their mini-corpus analysis, Hewings and Hewings (2005: 99-100) note that some reporting structures in conversational settings have been ignored in the grammatical consideration of the topic because of their overemphasis on "written data", and "oral narrative" within "spoken data". This means that for practical reasons (limited availability of spontaneously produced spoken data), our students ${ }^{11}$ are asked to observe indirect discourse in TV films, serials and documentaries as well as in plays of some contemporary authors.

The general feature and natural restriction of the spoken mode of communication is the length and the complexity of the reported utterances: these can neither be too long nor too complex. A second characteristic, in contrast to, for example, news reporting, is that the communication mediator, i.e. the speaker, has often been personally involved

11 Indirect discourse through different types of discourse is taught to third-year B.A. students attending the course on English-Slovenian Contrastive Grammar at the Department of Translation, Faculty of Arts, University of Ljubljana. 
in the reported discourse, either as the original speaker or the original hearer (be s/he an intentional or unintentional hearer). As the mediator has often been directly involved in original communication, it may be expected that his or her primary focus will be on the communicated message rather than on the original communicator. Therefore the mediator's report will often result in direct speech reporting rather than indirect discourse at all.

The preference for direct speech is especially true of past speech reporting in which several interlocutors, with their respective turns, are involved. The mediator gives a fairly verbatim report of the past conversation, opting for lively, seemingly mimetic discourse, furnished with utterance-openers such as oh, well, look, okay (LGSWE 1999: 1118), and including imperative sentences and direct questions:

Yeah, he went "Oh!" He goes, "Who put that there?" And the bit where he goes he she goes "Piss off!" like that and the mother goes "You talking to me?" (BrE) goes "Urgh, cobwebs," and she goes "Piss off!" She goes "Mum, come and sit here," (ibid.: 1119).

In conversation, the secondary speaker often chooses to focus on the communicated message, especially if the speaker wants to stress the current relevance of the reported statement:

"You said you can fix it." (Family Law*)

"Did you tell Chandler that some guy from work is the funniest guy you know?" $($ Friends $*)$

The current relevance of the communicated message is not restricted to habits and states; it may include past actions. References to past actions show a general tendency towards tense simplification in conversation, especially in American English:

"Did Rachel tell you we hired a male nanny?" (Friends*)

In the above example, hired remains in the original Past Tense. The mediator's focus on the original communicator is more likely with discrete utterances than it is with lengthy stretches of conversation. There are pragmatic and semantic reasons for the mediator's distanced attitude towards the original communicator; hence the backshift in the communicated message. With the distanced attitude, the mediator prefers to delegate the responsibility to the original communicator, since the communicated message sounds incredible or is not to the liking of the speaker. This is the case in the following example, where the speaker refuses to identify with the insulting remark:

"Beth told me that everyone in class hated my guts." (Cosby Show*)

If we compare the next two examples, we shall see that the use of the non-backshifted tense form in the second example suggests that the speaker more readily identifies with McDonald's viewpoint on diet: 
"The doctors said that fast food was killing me." (Dr. Phil*)

"McDonald's said the stuff is nutritious." (Dr. Phil*)

Another pragmatic convention involves statements with hypothetical meaning, especially those expressing futurity, such as will + infinitive and be going + to-infinitive structures:

"I told him I would see him tomorrow night." (Friends*)

Backshifting in hypothetical situations may also be seen in the light of the mediator's lack of confidence, and this is comparable to the utterance's lacking credibility. The opposite is true with stative situations, such as general or universal truths and habits. No backshifting may be expected there as these actions appear to be rather atemporal, temporally unrestricted:

"They said that these law suits are frivolous." (Dr. Phil*)

The complexity of indirect discourse in conversation can hardly match the ease with which this topic is treated in some textbooks and calls for a more sensitive approach to the teaching of indirect discourse functions in conversation.

\section{SEMANTIC CONVENTIONS}

The mediator's attitudinal distance or proximity towards the communicated message is primarily governed by the semantic features of the reporting verbs associated with the original communicator. As has been mentioned, communication verbs belong to three basic semantic groups: mental verbs, speech act verbs, and other communication verbs. Empirical data show that mental verbs trigger tense-backshift, as can be observed in the following conversation example:

\section{"He thought she was being killed." (The Practice*)}

Mental verbs function as "mediators" of the original communicator's cognitive, emotional and physical perception of what is being communicated, so the communicated message is more tightly bound to the original past time-sphere. Declerck shows that mental verbs such as believe, suppose, think "prohibit any shift of domain that would do violence to the structure of the belief in question" (Declerck 1991: 189). We notice, however, a tendency towards tense simplification with past actions in conversation, especially in American English. This means that the Past Tense in indirect statements may refer either to backshifted Present Tense statements or non-backshifted Past Tense statements in the original communication settings. Without sufficient context it may be difficult to tell whether the Past Tense didn't date in the following example has been backshifted or not:

"I thought she didn't date clients." (Full Circle*) 
If such statements are not complemented by more context or a further description of the situation, the learner is left without vital information regarding the application of tense-backshift - and the above example proves to be dysfunctional.

We also notice that in popular academic on-line contributions, backshifted or non-backshifted tenses in indirect messages with mental verbs will reflect the level of general or scientific validity of the communicated ideas. In the following text, published within a community of mathematicians, there are three mental verbs, believe, realise and know in the past tense, while the original communicators are ancient civilizations and the rather generic subject people:

Ancient civilizations like the Greeks and the Egyptians believed that gods named Helios and Ra carried the Sun across the sky everyday in its journey around the Earth, and it wasn't until much later that people realised it's actually the Earth that orbits the

Sun. Even with this mistake they knew that the position of the Sun changes over time to make the seasons in a cycle lasting around 365.25 days, a solar year. ${ }^{12}$

We see that the communication mediators adopt a distanced (external) attitude towards the (backshifted) original mythical idea defended by Ancient civilizations, while they identify with the modern "people's" views based on astronomical observations.

Speech act verbs, e.g. say, tell, can be treated as neutral communication verbs. They do not automatically trigger tense-backshift. Rather, the decision is dependent on the discoursal conventions and the mediator's attitude, as discussed in the above sections.

Meanwhile, other communication verbs, such as show, prove, suggest, are associated with the communicated message rather than with the original (inanimate) communicator, e.g. the findings; hence, they tend not to trigger tense-backshift. These verbs are typically used in academic prose, where the author prefers non-mediated temporal placement of the communicated message.

\section{STYLISTIC AND SYNTACTIC CONVENTIONS}

The stylistic-syntactic convention of tense simplification, i.e. "the tendency to replace a tense that has a complex temporal structure by a simpler tense wherever possible" (Declerck 1991: 183), is typically used in situations with temporal indications and with hypothetical or counterfactual conditions. Irrespective of the type of discourse, empirical data predominantly support the stylistic-syntactic convention that there is no backshift with verb situations in temporal clauses within the past time-sphere. However, this syntactic-stylistic convention is not always applied as is illustrated by the following newspaper example:

Police said that the pilot had sent out a distress call at $5.50 \mathrm{pm}$, just before the crash.

Witnesses reported a "powerful and violent explosion." (The Guardian*)

12 Source: http://www.mathscareers.org.uk/article/day/ (Accessed 28 July 2014). 
We notice that in the above example the Past Perfect may have been preferred because of a further temporal reference indicating the following event just before the crash.

\section{SYNTACTIC RESTRICTIONS}

These restrictions involve the syntactic ordering of the subordinate clauses. The deeper the sentence structure goes, the less likely it is that the sequence of tenses will be observed with respect to the time of orientation in the main clause, so the communication mediator's focus will be on the communicated message rather than on the original communicator. The tenses in the subclauses will be temporally subordinated to the implicit time of orientation of their superordinate clause, their matrix (Declerck 1991: 62-63), as is illustrated by the following example:

Reports said that five people had died including Signor Fasulo, who was alone in the aircraft. [...] It was believed that the pilot, distracted by problems trying to lower the undercarriage, had failed to notice how close he was to the building (The Guardian*).

In the above example the first-mentioned indirect subordinate clauses observe the tense-backshift with the Past Perfect in had died and had failed to notice, while the deeper-lying subordinate clauses with was remain non-backshifted.

\section{CONCLUSION}

The article shows that over-generalized grammatical descriptions of tense-backshift in English indirect discourse will not provide sufficient or reliable guidelines for the development of the communicative competence in indirect discourse. The CEFR makes it clear that the communicative competence is formed through the inclusion of the linguistic, sociolinguistic and pragmatic components, which can all be observed in the case of indirect discourse usage. Learners should be encouraged to study indirect discourse in (segments of) authentic, spontaneously produced texts. While corpus concordances indicate recurrent patterns in language use, it is primarily through exposure to (the respective) primary discourse sources that learners can best develop their own written and oral production skills.

Whether or not the learner's native language has an option of tense-backshift, English indirect discourse should be taught and studied with respect to its occurrence in different types of discourse (written and spoken, diegetic and mimetic) and with a heightened awareness of the communication mediator, who, on the basis of the type of discourse and his/her own involvement in the communicative situation, forms indirect discourse. It is exactly the role of the communication mediator that learners of English will adopt when producing their own instances of indirect discourse. 


\section{Bibliography}

AIJMER, Karin (2009) Corpora and Language Teaching. Amsterdam: Benjamins.

BIBER, Douglas et al. (1999) Longman Grammar of spoken and written English. London: Longman.

BRINTON, Laurel J./Donna M. BRINTON (2010) The Linguistic Structure of Modern English. Amsterdam: Benjamins.

CARTER, Ronald et al. (2011) English Grammar Today. An A-Z of Spoken and Written Grammar. Cambridge: Cambridge University Press.

DECLERCK, Renaat (1991) Tense in English: its structure and use in discourse. London/New York: Routledge.

FLEISCHMAN, Suzanne (1990) Tense and narrativity: from medieval performance to modern fiction. London: Routledge.

FOWLER, Roger (1996) Linguistic criticism. Oxford/New York: Oxford University Press.

JACOBS, Roderick A. (1993) English Syntax: a grammar for English language professionals. Oxford: Oxford University Press.

HEWINGS, Ann/Martin HEWINGS (2005) Grammar and Context. London/New York: Routledge.

LEECH, Geoffrey N./Jan SVARTVIK (1975) A Communicative Grammar of English. Harlow: Longman Group.

LEECH, Geoffrey N./Mick H. SHORT (1995) Style in Fiction. London: Longman.

OREL KOS, Silvana (2008) "A contrastive-stylistic study into the tense distribution in English and Slovene fictional texts." Linguistica 48, 227-236.

PAYNE, Thomas E. (2011) Understanding English Grammar. A Linguistic Introduction. Cambridge: Cambridge University Press.

\section{Abstract \\ DISCOVERING ENGLISH TENSE-BACKSHIFT PARAMETERS THROUGH DISCOURSE}

English grammars and teaching materials often fail to include references to specific discoursal and communicative functions. This facilitates the foreign language acquisition process during which learners acquire basic linguistic skills. The teaching of indirect discourse or so-called reported speech is no exception in this respect: easy-to-learn grammatical rules governing tense-backshift are combined with rather open-ended communicative functions. The CEFR 2011, however, aims at developing the user's communicative competence, which at its most naturally-occurring level includes the pragmatic-discursive components. The article presents a discourse-oriented approach to indirect discourse teaching and learning, in which the role of the communication mediator, i.e. the indirect discourse producer, is presented as one of the most significant 
parameters that have been analytically disregarded, yet it provides an identification model for the learner as an active language user. Our approach focuses on further important parameters of indirect discourse, i.e. the discoursal macrotextual type, the focus on the original communicator or the message, the communication mediator's attitude or involvement, semantic, stylistic and syntactic restrictions. The suggested discourse-oriented approach encourages students to discover "grammatical rules" on their own, which should enable them to develop more internalized and confident language production skills.

Keywords: indirect discourse, English, tense-backshift, discourse types, communication mediator.

\section{Izvleček \\ ODKRIVANJE PARAMETROV SOSLEDICE GLAGOLSKIH ČASOV V ANGLEŠČINI SKOZI DISKURZ}

V angleških slovnicah in učnem gradivu pogosto niso upoštevane specifične diskurzivne in komunikacijske funkcije, kar sicer olajšuje razvijanje osnovnih jezikovnih veščin $\mathrm{v}$ procesu usvajanja tujega jezika. $\mathrm{V}$ tem pogledu ni izvzeto niti poučevanje indirektnega diskurza "reported speech": lahko naučljiva slovnična pravila o rabi sosledice glagolskih časov v angleščini se prepletajo z dokaj nedoločnimi komunikacijskimi funkcijami. SEJO 2011 se osredinja na razvoj uporabnikove sporazumevalne zmožnosti, ki v svoji najbolj naravni pojavni obliki vsebuje tudi pragmatično-diskurzivne sestavine. $\mathrm{V}$ prispevku je predstavljen diskurzivni pristop k poučevanju in učenju indirektnega diskurza. Eden najpomembnejših parametrov, ki doslej ni bil deležen analitične pozornosti, je vloga komunikacijskega posrednika, tj. tvorca indirektnega diskurza, saj ravno ta predstavlja identifikacijski model za učenca kot aktivnega uporabnika jezika. V prikazanem pristopu so opisani nadaljnji pomembni parametri indirektnega diskurza, tj. makrobesedilni tip diskurza, izpostavljanje izvirnega sporočevalca ali sporočila, odnos ali vpletenost komunikacijskega posrednika ter semantične, slogovne in skladenjske omejitve. Predlagani diskurzivni pristop spodbuja študente k aktivnemu odkrivanju »slovničnih pravil«, kar naj bi jim olajšalo razvijanje bolj ponotranjenih in trdno usvojenih veščin tvorjenja jezikovnih sporočil.

Ključne besede: indirektni diskurz, angleški jezik, sosledica glagolskih časov, diskurzivni tipi, komunikacijski posrednik. 